\title{
Statyba
}

\section{ON THE STRENGTH RESERVE OF CONCRETE STRUCTURES DUE TO CONDITIONS OF RESTRAINED FLEXURE}

\section{Janas \& Dr Eng J. Sokół-Supel}

To cite this article: M. Janas \& Dr Eng J. Sokół-Supel (1999) ON THE STRENGTH RESERVE OF CONCRETE STRUCTURES DUE TO CONDITIONS OF RESTRAINED FLEXURE, Statyba, 5:6, 399-404, DOI: $10.1080 / 13921525.1999 .10531495$

To link to this article: https://doi.org/10.1080/13921525.1999.10531495

曲 Published online: 26 Jul 2012.

Submit your article to this journal $₫$

Џ Article views: 60 


\title{
ON THE STRENGTH RESERVE OF CONCRETE STRUCTURES DUE TO CONDITIONS OF RESTRAINED FLEXURE
}

\author{
M. Janas, J. Sokól-Supel
}

\section{Restrained flexure}

Simple flexure means transversal bending of flat structures in absence of membrane forces. Bending with in-plane displacements at supports prohibited or restricted is called here restrained flexure; the term is introduced per analogiam to restrained torsion. For structures composed of "symmetric" materials (with the same strength/ elasticity characteristics in compression and tension) the simple flexure induces existence of a neutral plane (axis) free of deformation; therefore, even if in-plane restraints at support exist, they do not generate membrane forces. The latter will appear eventually and they may be of some importance only at very advanced deformation. However, if elastic and/or strength characteristics of the material are different in tension and in compression, the restraints may change qualitatively the structure response from the very beginning of the deformation process. For example, in the case of brittle-matrix composite structures the end fixity generates important compressive membrane forces. This effect, known as the arching action in $\mathrm{RC}$ beams [1] and slabs [2] strengthens considerably the structure but makes its response strongly unstable. The geometrical nonlinearity inherent to the behaviour of eccentrically compressed slender bars is enhanced here by the deformationdependence of the membrane forces. Therefore, geometrically linear analysis is unacceptable, in the considered cases, even for quite non-slender structures. The character of the load-deflection behaviour under restrained flexure is shown in Fig 1.

Of course, such behaviour makes useless standard methods for determination of ultimate loads based on the limit analysis approach. A geometrically non-linear elastic-plastic analysis is needed, which is feasible now using commercial FEM codes. However, the procedures are rather laborious and, first of all, very sensitive to input data and to modelling support conditions. Important un- certainty concerning these data makes engineers reluctant in accounting for the discussed effect. Therefore, an approach, of the level of simplicity similar to that encountered in the strength of materials is needed. Such type of approach will be presented in Sec 3 .

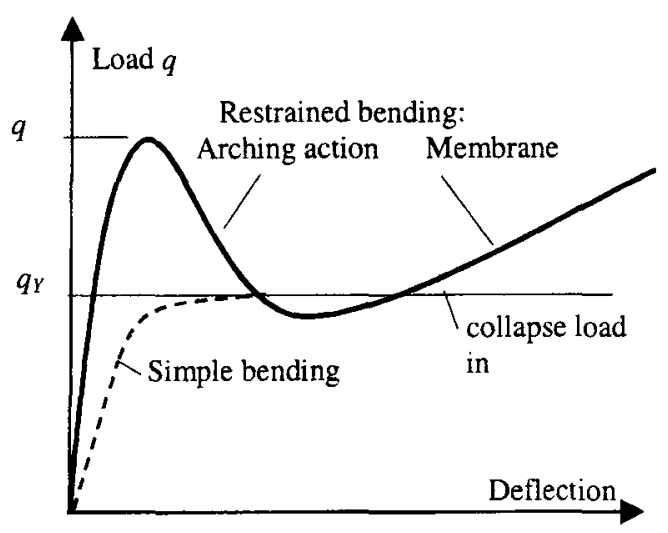

Fig 1. Load-deflection response to restrained flexure of reinforced brittle-matrix structures

\section{FEM simulation and material modelling}

Preliminary results of a geometrically non-linear analysis of one-way RC slabs presented in [3] have been obtained using ABAQUS code for no-tension elasticperfectly plastic model of the concrete matrix and elasticperfectly plastic reinforcement. Here, the study was extended to different geometrical, material characteristics and support restraints. To give an idea on the quantitative importance of the effect, load-deflection curves are given in Fig 2 for clamped centrally loaded strips. Results are given for a thick strip (with span-to-thickness ratio $\mathrm{L} / \mathrm{h}=10$ ) and for a slender structure $(\mathrm{L} / \mathrm{h}=30)$. In both cases an unreinforced structure and strongly reinforced one $(1.6 \%)$ are considered. Results are compared with those for simple unrestrained bending. 


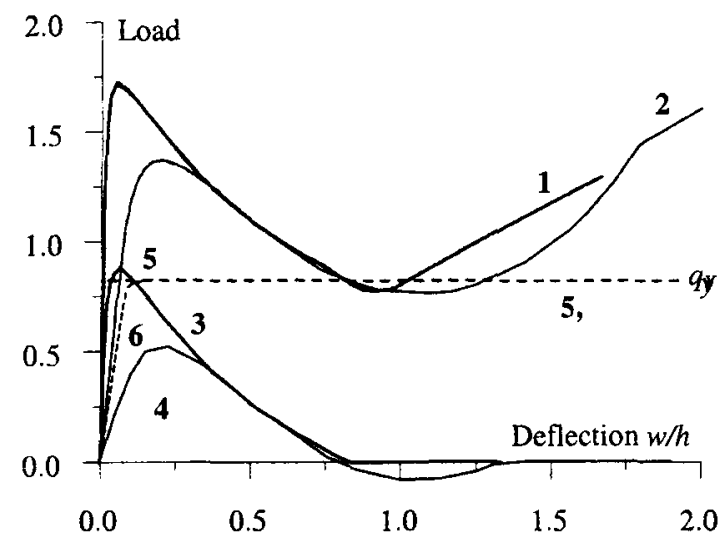

Fig 2. Load-deflection behaviour of clamped restrained strips; $1,3,5$ - thick $(L / h=10) ; 2,4,6-\operatorname{sim}(L / h=30)$; $1,2,5,6$ - reinforcement $1.6 \% ; 3,4$ - unreinforced; 5,6 - simple bending

Different approximations of the compressive response of the concrete (Fig $3 \mathrm{~b}$ ) were considered. It appeared, as seen from Fig 3 a, that the shape of the stressstrain curve has small impact on the most important feature of the structure behaviour: its ultimate-peak load; this value is predominantly dependent upon the yield stress and the initial elastic modulus. This conclusion confirms that the simplest bi-linear model may be accepted in the parametric study.

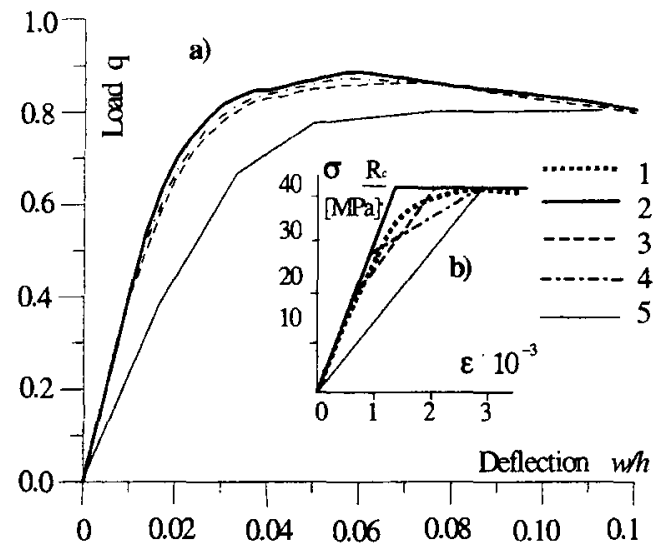

Fig 3. a) Load-deflection behaviour of an unreinforced clamped strip for $b$ ) different approximations of the real stress-strain curve (1): 2 - bi-linear approximation using the initial modulus; 3,4-tri-linear, 5-bi-linear with a secant modulus

Computations for some benchmark cases were performed using the concrete tensile-softening model (Fig 4) to determine the influence of the tensile strength of the material. To reduce the mesh sensitivity of the simulation the Hilleborg fracture energy approach [4] was applied. It appears that even in the case of a plain concrete strip, where the stiffening tension effect should be the most important, its influence disappears well before the load attains its ultimate value. Therefore, the use of the notension model for the concrete seems to be quite justified.

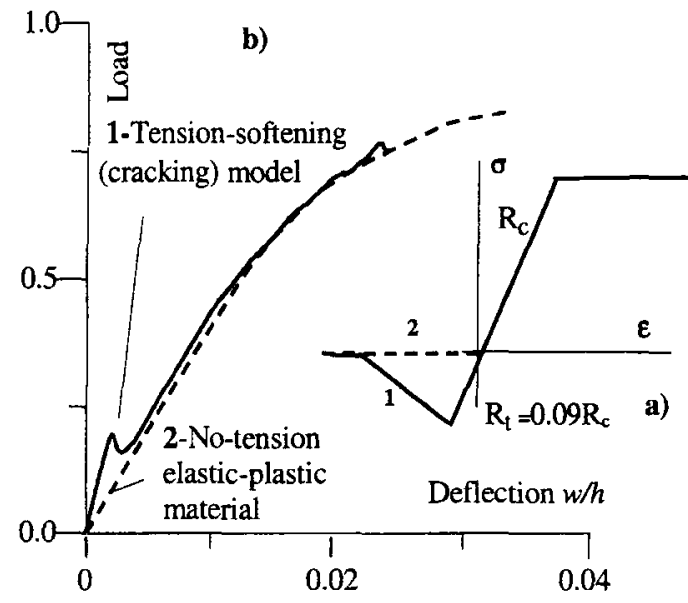

Fig 4. a) Tension-softening and no-tension models for concrete b) - Comparison of results for a clamped unreinforced strip

All the results presented above concern fully restrained (clamped) concrete strip under point load at the mid-span. In the case of very compliant supports these conclusions may be no more valid but the effect of the arching action will be, then, of small importance and the simple bending approach becomes preferential.

\section{An approximate post-yield approach}

As it has been already explained, the popular limit analysis approach is useless for determination of the collapse load of structures undergoing restrained bending. First, it should be remarked that the simple bending approach to the limit analysis (eg, the yield-line method) gives erroneous results, when applied to the structures composed of "non-symmetric" materials and when bending moments change the sign. It is easy to see, when an internal compatibility in the cross-section at yielding is examined (eg, [5]) that such analysis appears, in reality, kinematically inadmissible. This fact is responsible for the known yield-line paradox: test results are frequently superior to the upper-bound estimations of the collapse. load furnished by the yield-line method. However, when a consistent limit analysis procedure is applied to these 
cases, the collapse loads obtained ( $g_{0}$ in Fig 5) are largely superior not only to the simple bending results $q_{Y}$, but also to real supportable loads $q_{U}$ (Figs 1,5 ). The reason of this discrepancy is evident: the limit analysis theory deals with the incipient flow mechanism and does not account for geometry changes due to the prior-to-collapse deformation.

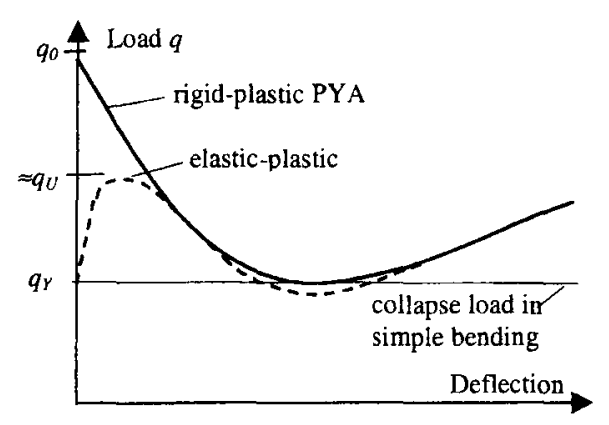

Fig 5. Simulation of restrained flexure by a rigidplastic and elastic-plastic post-yield approaches

To take into account, in some manner, the geometry changes a so-called post-yield approach (PYA) was used already long ago [6], especially for concrete slabs [2]. It consists of applying the kinematical method of the limit analysis theory to structures with their geometry modified following the plastic collapse mode. This mode may correspond to the initial plastic flow or may be modified during the deformation process. In this way a loaddeformation curve may be obtained corresponding to a sequence of instantaneous collapse loads for a consecutively deformed structure. However, this curve descends from the initial rigid-plastic collapse load $q_{0}$, which can be never attained because of prior-to-collapse elasticplastic deformations. These deformations cannot be determined from the rigid-plastic analysis. Unfortunately, if an elastic-plastic model were used, the main advantage of the post-yield approach - its simplicity - would be lost. However, it appears that only elastic deformations due to membrane forces are responsible for qualitative differences between the real structural response and its rigidplastic modelling.

Taking into account the elastic membrane compliance and neglecting flexural deformations outside the yield lines (plastic hinges) permits for an approach $[7,8$, 9] that describes well, at least qualitatively, the structure behaviour, when conserving the simplicity of the postyield analysis. This elastic-plastic PYA simulation may strongly differ from the real response only at the initial stage of the deformation (Fig 5). Namely, it neglects flexural elastic deformations and, therefore, commences the load-deflection curve at flexural collapse load $q_{Y}$. However, this phase is of minor interest when the structure carrying capacity is concerned. In the vicinity of the ultimate-peak load, the simulation appears quite satisfactory.

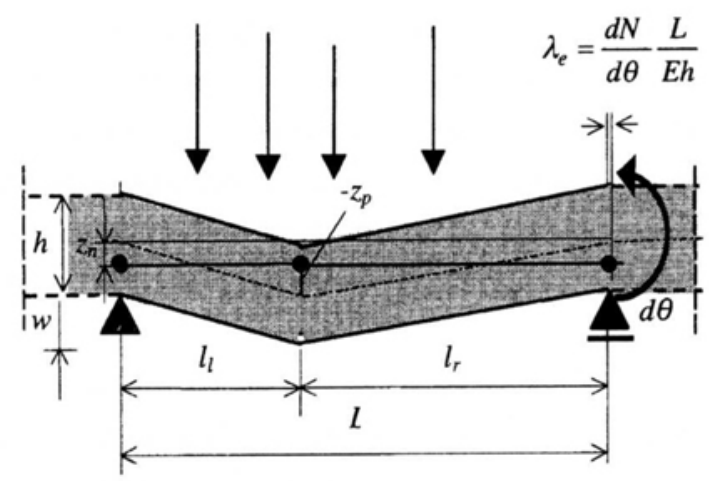

Fig 6. Kinematics of an instantaneous flow of the deformed strip

Let us recall the idea of this approach [7] using a classical case of a multi-span strip collapsed following a three-hinge mode, Fig 6 . If a virtual rotation increment $d \theta$ is applied to a rigid-plastic strip pre-deformed following the initial flexural collapse mode, kinematical compatibility needs the vectors of relative rotation increments in the plastic hinges (black dots in Fig 6) to be co-planar. If plastic properties in the two plastic hinges at supports are the same (the case chosen for simplicity of the demonstration), this plane (instantaneous neutral plane) is parallel to the reference plane of the undeformed structure. It means that the positions of neutral axes $z_{n}$ in the support (negative) hinges and $z_{p}$ in the positive one should satisfy the relation: $z_{p}=z_{n}-w$. However, if the strip and its supports are assumed to submit elastic membrane deformations proportional to the membrane force increment $d N$, this relation becomes:

$$
z_{p}=z_{n}-w-\frac{d N}{d w} \frac{l_{l} l_{r}}{L}\left(C_{b}+C_{s}\right)
$$

where $L$ is the strip span, $h$ is its thickness, $z_{p}, z_{n}$ determine positions of instantaneous neutral axes in positive and negative plastic hinges (Fig 6), $N$ denotes the membrane force per unit width of the strip (compression taken 
positive), $l_{l}, l_{r}$ describe the positive hinge location in the collapsed span $L ; C_{b}, C_{s}$ are the strip compliance and an added in-plane elastic compliance of both supports (per unit width), respectively. It should be remarked that the strip elastic compliance

$$
C_{b}=\frac{L}{E h}
$$

may represent only an approximation for the average membrane compliance of the deformed part of the structure between the support plastic hinges. In reality, for plastic no-tension material its value is moment dependent and, therefore, varies along the axis and through the deformation process. Since $C_{b}$ is assumed constant, its reduced average value $C_{b r}$ should be estimated using a more exact incremental analysis, as described in Sec 2 (see [3] ).

It will be more convenient to use, instead of the compliance, a non-dimensional in-plane elastic stiffness of the system $\varepsilon$ related to the elastic modulus $E$ and the concrete compressive strength $R$ :

$$
\varepsilon=\frac{2 L h}{l_{l} l_{r}} \frac{1}{R\left(C_{b r}+C_{s}\right)} .
$$

The relation (1), together with the yield criterion for plastic hinges described with $z_{p}, z_{n}$ (see, e g, [7]) and with the in-plane equilibrium condition, give a linear differential equation permitting for determination of the membrane force evolution $N=N(w)$. Then, the limit equilibrium of the deformed system (Fig 6) permits to establish the load-deflection relation, Fig 5 . It commences with the simple bending collapse load $q_{Y}$ at displacement $w=0$, attains its maximum (ultimate-peak load $q_{U}$ ) at deflection $w_{U}$ and a minimum value slightly inferior to $q_{Y}$. Shortly afterwards a pure membrane response commences. This relation, $q=q(a)$ expressed in nondimensional values, is as follows (for details see $[3,7]$ ):

$$
q=q_{Y}+(k-\alpha)^{2}-\varepsilon^{-2}\left[k \varepsilon-\left(1-e^{-\varepsilon \alpha}\right)(1+k \varepsilon)\right]^{2} .
$$

The non-dimensional load $q$ is related to the load through the maximum value of the bending moment $M_{\max }$ calculated (per unit strip width) as in a simple supported span and to the unit plastic moment for symmetric material $M_{p}=R h^{2} / 4$ :

$$
q=\frac{4 M_{\max }}{R h^{2}} .
$$

The non-dimensional displacement at the positive hinge is $\alpha=w / h$. The parameter $k$ depends upon the properties of the cross-sections at hinges. For double near-to-face reinforcement it is:

$$
k=1-\eta_{p}-\eta_{n}+\eta_{p}{ }^{\prime}+\eta_{n}^{\prime},
$$

where $\eta_{i}$ describes the intensity of the reinforcement in the $i$-th layer, with the yield point $Q$ and with the crosssection area $A_{i}$ :

$$
\eta_{i}=\frac{Q A_{i}}{R h}
$$

Subscripts $i=(p, n)$ denote the positive (span) and negative (support) plastic hinges and the superscript (') concerns compressed reinforcement (taken here $\eta_{i} \geq \eta_{i}^{\prime}$ ). Hence, for unreinforced or symmetrically reinforced notension cross-sections we have $k=1$. For uniform crosssections made of a ductile but non-symmetric material, expression for $k$ should be slightly modified (see [7]); for symmetric materials it gives, of course, $k=0$ and we return to the simple bending, with the collapse load $q_{Y}$.

Depending upon the value of the in-plane elastic stiffness of the structure expressed by the parameter $\varepsilon$ the relation (4) describes behaviour ranging from the rigidplastic response to simple (unrestrained) bending. Some results from (4) are given in Fig 7.

It appears that the ultimate load $q_{U}$ is attained at a deflection $w_{U}$ equal nearly exactly to the half of the value corresponding to the maximum of the membrane force and may be taken as:

$$
w_{U}=\frac{h \ln (1+k \varepsilon)}{2 \varepsilon} .
$$

Hence, the ultimate load $q_{U}$ may be expressed, using eqs $(4,8)$, with the formula:

$$
q_{U}=q_{Y}+\varepsilon^{-2}\left[(k \varepsilon-\ln \sqrt{1+k \varepsilon})^{2}-(\sqrt{1+k \varepsilon}-1)^{2}\right] .
$$

\section{Incremental (FEM) and experimental validation of the PYA method}

As mentioned above, for non-elastic (no-tension) materials the in-plane compliance $C_{b}$ depends, in reality, upon the moment-to-force ratio; therefore, it varies along the structure axis and throughout the deformation process. In the PYA method this value is taken constant, which is exact for elastic symmetric materials. This assumption 
may be considered acceptable if a reduced value $C_{b r}$, used instead of $C_{b}(2)$, is chosen in such a manner that the resulting simulation of the structure response at ultimate load will be sufficiently similar to the response obtained from a complete incremental FEM analysis discussed in Sec 2. A parametric study for different load and support conditions (eg, different support compliances, anchored or unilateral in-plane supports, etc) shows that a surprisingly good agreement in results of the two approaches may be obtained. A satisfactory fit in the ultimate load $q_{U}$ and in the corresponding deflection will be obtained if the reduced strip compliance $C_{b r}=L / E_{r} h$ is determined using a reduced Young modulus $E_{r}$ taken a half of the material value $E$.

Comparison of analytical (4) and incremental FEM results is given in Fig 7 for the early stage of the loaddeflection behaviour of the structural cases presented in Fig 2. The fit of the descending and membrane-ascending parts of the curves (see Fig 2) is nearly perfect. To obtain a satisfactory fit in the pre-membrane phase for slender structures an intermediary PYA solution (see [7]) should be used. However, this phase is beyond of our interest here.

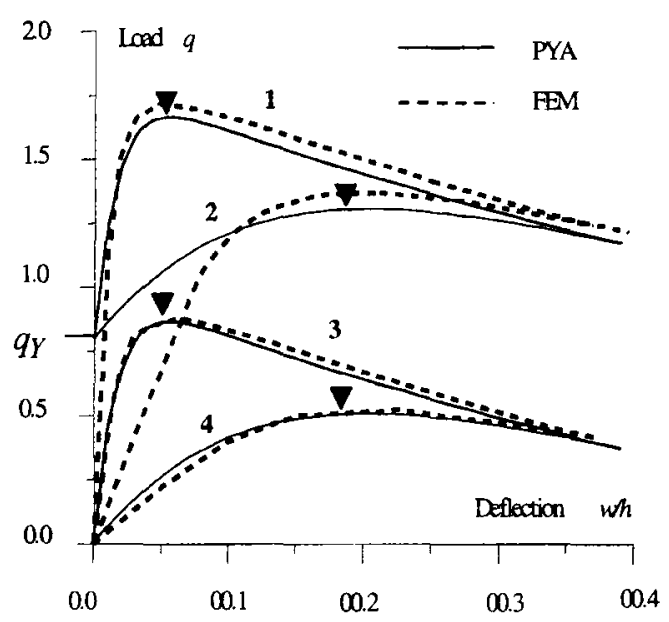

Fig 7. Early stage of clamped strips response - comparison of FEM and PYA results. 1, 3 - thick strips $(L / h=$ $10) ; 2,4-\operatorname{slim}(L / h=30) ; 1,2$ - reinforcement $1.6 \% ; 3$, 4 -unreinforced. $=-q_{U}, w_{U}$ following $(8,9)$

The fit in the ultimate load will be slightly better if some contribution of the reinforcement to the compliance is accounted for, especially for compliant supports. Such approximation

$$
E_{r}=\frac{E}{2}\left(1+4 \eta_{p}+4 \eta_{n}\right)
$$

is used for the comparison of load-deflection PYA curves (4) with the FEM incremental analysis for compliant supports that is given in Fig 8. The case concerned there is a medium-slenderness $(L h=15)$ concrete strips unreinforced or bottom-reinforced and loaded with a force at mid-span. Supports were hinged with an assigned in-plane compliance. Black triangles denote the ultimate values obtained from the formulae (8) and (9).

Selected results of a series of tests on reinforced concrete strips are also given in Fig 8 . The specimens of the size $90 \times 6 \mathrm{~cm}$ were simply supported and restrained against horizontal displacements with blocks of different horizontal compliance. Results presented concern a strong restraint $\left(C_{s}=C_{b}\right)$ and bottom reinforcement of intensity $\eta_{p}=0.09$. The goal of the tests was, first of all, a qualitative demonstration of the importance of the arching action on the supportable load of RC structures and the influence of the support compliance. The restraints induced an average rise in the ultimate supportable load by $53 \%$ up to $171 \%$ for strong $(\eta=0.18)$ and weak $(\eta=$ 0.09) reinforcement, respectively. For unreinforced structures the effect was, of course, the most important; the rise was as high as $600 \%$.

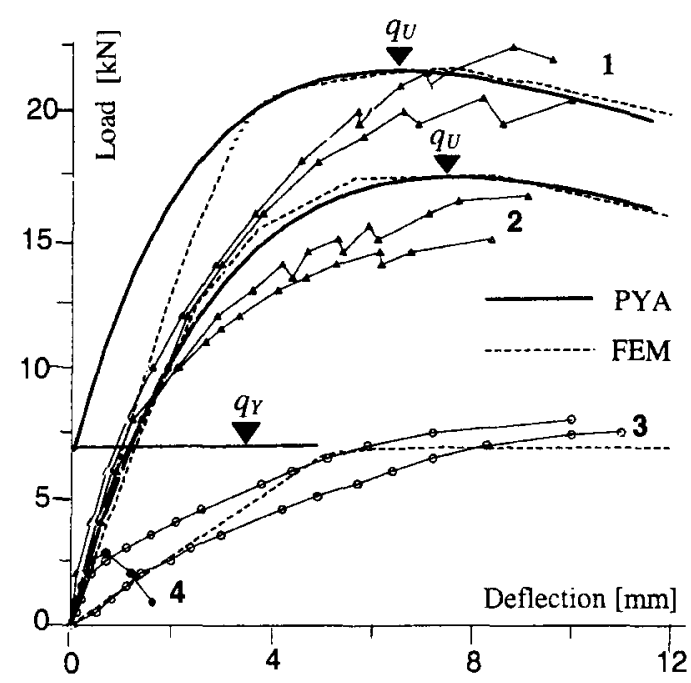

Fig 8. FEM-incremental, PYA-analytical (4) and experimental results for 3-points tests on plain and reinforced concrete strips with compliant in-plane supports; strips: 1 - restrained reinforced, 2 - restrained unreinforced, 3 - unrestrained reinforced, 4 - unrestrained unreinforced 


\section{Final remarks}

It appears that the simple method based on the postyield approach permits for determination of the ultimate supportable load for $\mathrm{RC}$ one-way slabs with a reasonably good approximation. Degree of complexity of the analysis does not exceed the level in the elementary structural mechanics (strength of materials level). No more than knowledge of limit analysis for beams is needed.

The same approach is applicable to two-way slabs, using the yield-line method. However, for this need a more extensive parametric study is still necessary.

Initial deflections, structural gaps and thermal effects may be easily included into the approach (see [7]). This possibility is of importance, because these effects may seriously influence the value of the ultimate load.

Finally, it should be once more underlined that restrained flexure may produce a very important reserve of the structure but makes its response very sensitive to support conditions and even to effects that engineers are frequently ready to disregard.

\section{References}

1. A. A. Gvozdev. The basis for the paragraph 33 of the reinforced concrete design code (in Russian) // Stroitelnaya Promyshlennost, 17, No. 3, 1939, p. 51-58

2. R. H. Wood. Plastic and Elastic Design of Plates. London: Thames-Hudson, 1961.

3. M. Janas, J. Sokót-Supel. Arching action revisited // Engineering Transactions, 43, 1997, p. 71-89.

4. A. Hilleborg, M. Modeer, P. E. Peterson. Analysis of crack formation and crack growth in concrete by means of fracture mechanics and finite elements // Cement and Concrete Research, 6, 1976, p. 773-782.

5. M. Janas. Kinematical compatibility problems in yield-line theory // Mag. Concrete Res., 19, 1967, p. 33-44.

6. R. M. Haythornthwaite. Beams with full end fixity // Engineering, 1957, p. 110-112.

7. M. Janas. Arching action in elastic-plastic plates // J. Structural Mechanics, 1, 1973, p. 277-293.

8. R. Park. Reinforced Concrete Slabs. New York: J. Wiley, 1980

9. J. R. Eyre. Direct assessment of safe strength of RC slabs under membrane action // J. Struct. Engng., ASCE, 123, 1997, p. 1331-1338.

Iteikta 19990920

\section{APIE BETONINIU KONSTRUKCIJU STIPRUMO REZERVA SUVARŽYTO LENKIMO SALYGOMIS}

\section{Janas, J. Sokól-Supel}

\section{Santrauka}

Suvaržyta lenkimą apibūdina skersinis 1enkimas, esant suvaržytiems arba neleistiniems atraminị tašku poslinkiams. Jei medžiagos tempimo ir gniuždymo savybès skiriasi, suvaržyti poslinkiai gali ił̌ esmés pakeisti konstrukcijos atsparuma. Betoninèse konstrukcijose atsiranda svarbios gniuždymo membraninès jègos. Šis reiškinys vadinamas arkos efektu $[1,2]$. Jis sustiprina konstrukcija, bet daro neigiamą itaką jos pastovumui (1 pav.).

Nagrinejami viena kryptimi armuotų gelžbetoniniu plokščių iteraciniai sprendimai, taikant baigtinius elementus ir tampraus-plastiško tempiamo betono modeli ( 2 pav.) bei skirtingas jo aproksimacijas. Analizè gali būti atliekama naudojant ir standartinę baigtinių elementų programą (ABAQUS), tačiau ji gana sudètinga ir jautri pradiniams duomenims. Todèl baigtiniu elementų programų panaudojimas inžineriniams tikslams yra abejotinas, reikia supaprastinto metodo. Toks metodas pateikiamas 3 skyriuje. Jo pagrindas yra netampraus (už plastinio deformavimo ribos) apskaičiavimo metodas, remtasi ir autoriy ankstesniais pasiūlymais $[3,7]$.

Metodas pagristas ribinès pusiausvyros metodu (standus plastinis modelis) (6 pav.), ivertinant tamprias plokštès ir jos atramu deformacijas. Metodo taikymas viena kryptimi armuotoms gelžbetoninèms plokštėms (4) leidžia kokybiškai tiksliai aprašyti apkrovos-ilinkio priklausomybę.

Analitiniai apskaiciavimo rezultatai (4) lyginami su iteracine BEM analizès rezultatais standžiaj itvirtintoms juostoms (7 pav.). Rezultatu atitikimas taikant abu metodus yra pakankamas, jeigu juostos vidutinis pasiduodamumas $C_{b r}$ yra lygus pusei tampraus pasiduodamumo (2). Rezultatai, gauti taikant abu metodus, yra palyginti su bandymų rezultatais ( 8 pav.), jvertinant jų priklausomybę nuo atramų plokštumoje pasiduodamumo. Deformuojamu atramu atveju geresnis rezultatu atitikimas yra gaunamas tuo atveju, kai ivertinama armavimo pasiskirstymo jtaka juostos standumui, skaiciuojamam pagal (10).

Paprastos aproksimacijos metodas, kuriam nereikia papildomц̨ žinių, priešingai negu kad elementari ribine analizé, leidžia patikimai jvertinti ribini vienos krypties armuotos suvaržytos plokštés stiprumą.

Marek JANAS. Professor. Head of the Division of Inelastic Structures at the Institute of Fundamental Technological Research (IPPT), Świętokrzyska 21, 00-049 Warsaw, Poland; E-mail: mjanas@ippt.gov.pl.

PhD (1964), Dr Habil (1976). From 1958 at the IPPT, 1965-67 associate at the Faculté Polytechnique de Mons (Belgium), 1982-95 lecturer at Université Joseph-Fourier (Grenoble, France). Research interests: applied plasticity (limit analysis, post-yield behaviour, shakedown); pressure vessels and liquid storage tanks (ultimate strength and stability). Books (in Polish): Limit Analysis of Arches and Vaults (Arkady, 1967); co-authored: Limit Analysis of Shells (Arkady, 1968), Plastic Analysis of Structures (Ossolineum, 1972).

Joanna SOKóL-SUPEL. Dr Eng, Assistant Professor. Institute of Fundamental Technological Research, Świętokrzyska 21, 00-049 Warsaw, Poland; E-mail: jsokols@ippt.gov.pl.

PhD (1973), 1979-80 associate at the National University of Mexico, 1985-86 associate at the Faculté Polytechnique de Mons (Belgium). Research interests: applied plasticity (plates, post-yield behaviour). Books (co-authored): Limit Analysis of Plates (PWN, 1993), Atlas of Limit Loads of Metal Plates Shells and Disks (Elsevier, 1995). 